\title{
Citrullinaemia with Rapidly Fatal Neonatal Course
}

\author{
S. P. M. VAN DER ZEE, J. M. F. TRIJBELS, L. A. H. MONNENS, F. A. HOMMES, \\ and E. D. A. M. SCHRETLEN \\ From the Department of Paediatrics, University of Nijmegen, Nijmegen, \\ and the Department of Paediatrics, University of Groningen, The Netherlands
}

\begin{abstract}
Van der Zee, S. P. M., Trijbels, J. M. F., Monnens, L. A. H., Hommes, F. A., and Schretlen, E. D. A. M. (1971). Archives of Disease in Childhood, 46, 847. Citrullinaemia with rapidly fatal neonatal course. An infant with a deficiency of argininosuccinate synthetase in liver and brain developed rapidly increasing apathy, respiratory insufficiency, and convulsions from the fourth day of life, and died on the seventh day. There was a profound derangement of amino acid concentrations in blood, CSF, and urine, with very high citrulline levels. This patient differs from other cases reported previously, both in her fulminant and fatal course in the neonatal period and in the greater biochemical disturbance.
\end{abstract}

Citrullinaemia is a rare inborn error of metabolism of the urea cycle. Only 3 cases have been reported previously (McMurray et al., 1962; 1963; McMurray et al., 1964; Mohyuddin, Rathbun, and McMurray, 1967; Morrow, Barness, and Efron, 1967; Morrow, 1967; Wick, Brechbühler, and Girard, 1970). The normal synthesis of argininosuccinic acid is blocked in this disease due to a deficiency of argininosuccinate synthetase, which has been demonstrated in liver cells and fibroblasts (McMurray et al., 1964; Tedesco and Mellman, 1967). The clinical symptoms are periodic vomiting and irritability, convulsions, and mental retardation. They are thought to be due to a chronic ammonia intoxication.

Our observation refers to a newborn infant with clinical features different from those of the other cases reported. Profound abnormalities in the pattern of amino acids of serum, CSF, and urine with very high levels of citrulline were found. Liver and cerebral cells were deficient in argininosuccinate synthetase.

\section{Case Report}

A girl, born 20 July 1970, was the second child of nonconsanguineous healthy parents. The pregnancy was uneventful. The baby was delivered by caesarean section at 38 weeks, because of a slightly narrowed maternal pelvis. The infant was normal at birth,

Received 5 April 1971. birthweight $2600 \mathrm{~g}$. One minute after birth the Apgar score was 10. She was breast-fed at first. During the first three days of life, the infant seemed to develop normally, sucking well. She became less alert on the fourth day and sucking became poor. Breastfeeding was changed to bottle-feeding of humanized milk. She became drowsy and hypotonic on the fifth day and breathing was depressed, and she was admitted to hospital, comatose. The Moro and sucking reflexes were absent. She was hypertonic and had frequent convulsions. The respiration was depressed. There was no cyanosis.

The blood $p \mathrm{H}$ was $7 \cdot 27, \mathrm{PcO}_{2} 6 \cdot 65 \mathrm{kN} / \mathrm{m}^{2}$, blood base excess $-4.5 \mathrm{mmol} / \mathrm{l}$., and serum bicarbonate $22.3 \mathrm{mmol} / 1$. The serum $\mathrm{Na}+$ was $144 \mathrm{mmol} / \mathrm{l} ., \mathrm{Cl}^{-}$ $107 \mathrm{mmol} / 1$., urea $2.54 \mathrm{mmol} / 100 \mathrm{ml}$., $\mathrm{Ca}++1.27$ $\mathrm{mmol} / 1$., and blood sugar $1.11 \mathrm{mmol} / 1$.

Glucose solution $(10 \mathrm{~g} / 100 \mathrm{ml})$ was administered intravenously $(5 \mathrm{ml} / \mathrm{hr})$. Calcium gluconate solution $(10 \mathrm{~g} / 100 \mathrm{ml})$ was injected intravenously $(15 \mathrm{ml})$. During the next few hours the convulsions stopped, but she became more hypotonic. Protein-free food was given by stomach tube. She remained comatose; the respiration was still inadequate with periods of apnoea. A respiratory arrest necessitated intubation and artificial ventilation. However, the general condition deteriorated gradually and the infant died on the seventh day of life.

\section{Family History}

The parents were unrelated. The mother's first pregnancy ended in an abortion. After a second uneventful pregnancy a boy was born by vacuum extrac- 


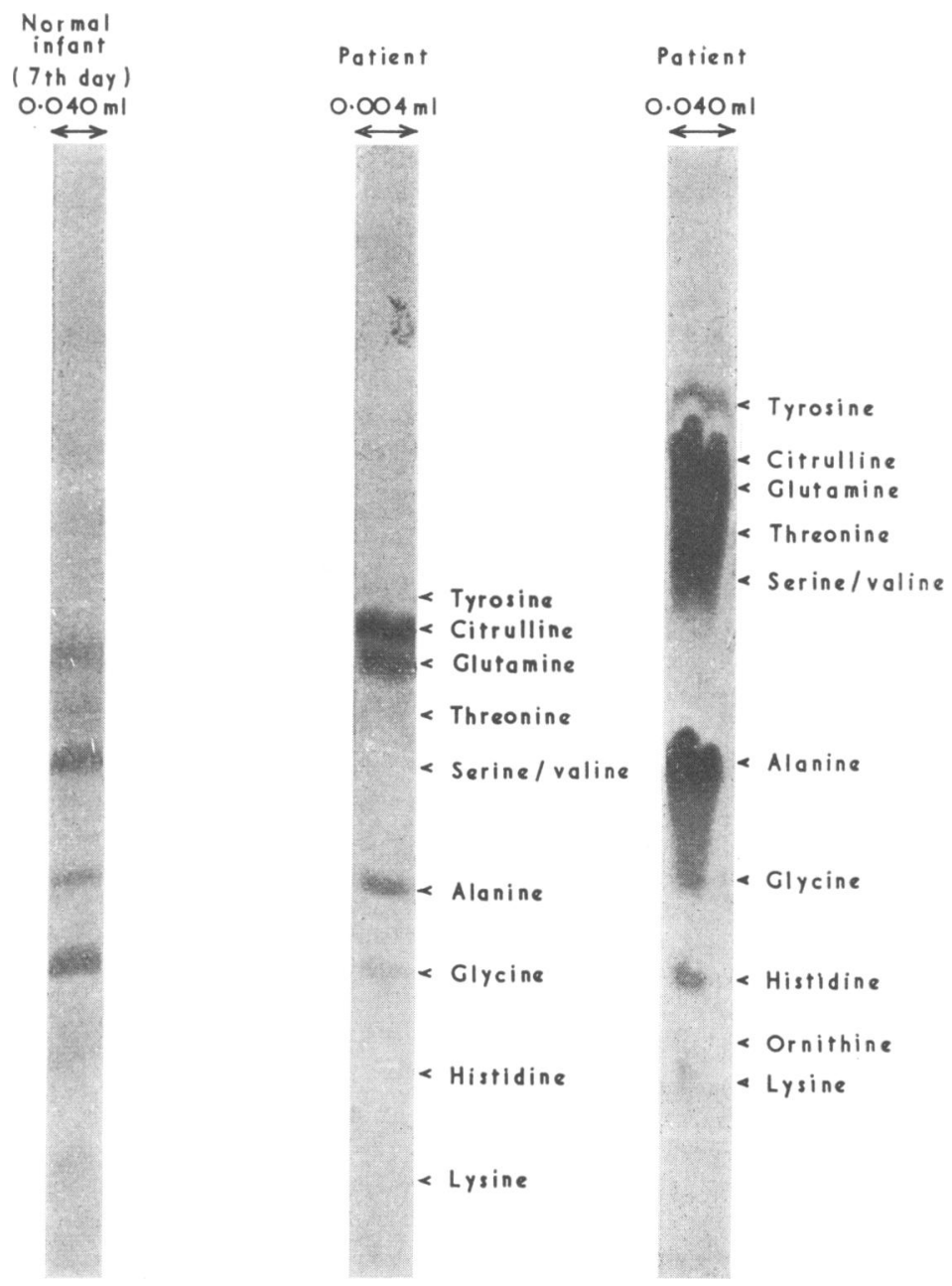

Fig.-High voltage electrophoresis of amino acids in patient's urine.

tion. This boy, the only sib of the proband, was normal at birth. He became lethargic on the fourth day of life and died suddenly. Necropsy revealed only a subdural haemorrhage.

\section{Methods}

Qualitative amino acid analysis of the patient's urine was performed by high voltage electrophoresis (CAMAG, Switzerland) on Whatman $3 \mathrm{MM}$ filterpaper, $40 \times 20 \mathrm{~cm}$, for $20 \mathrm{~min}$ at $100 \mathrm{~V} / \mathrm{cm}$ in formic acid : acetic acid : water (50:150:850, by volume), pH 2.0. Quantitative amino acid analyses of patient's serum, CSF, and urine were performed by elution chromatography with a Beckmann/Spinco Unichrom amino acid analyser. Deproteinization of the samples was carried out with sulphosalicylic acid. Enzymes of the urea cycle were assayed according to the methods described by Brown and Cohen (1959). Specimens of tissue were homogenized with a Potter-Elvejhem homogenizer with ice-cold $0.25 \mathrm{M}$ sucrose and $10 \mathrm{mM}$ triethanolamine, $p \mathrm{H} \mathrm{7 \cdot 4}$.

\section{Results}

Routine screening of the patient's urine by high voltage electrophoresis showed the presence of high amounts of citrulline (Figure). The concentrations of amino acids in the patient's serum are presented in Table I. A remarkable increase in the citrulline level was found (about four-hundredfold as compared to normal 5-day-old infants). Moreover, a high level was noted for methionine and to a lesser degree for glutamine, alanine glycine, proline and tyrosine. The concentrations of valine isoleu- 
TABLE I

Amino Acids in Serum of Patient with Citrullinaemia $(u m o l / l$.

\begin{tabular}{|c|c|c|c|}
\hline \multirow{2}{*}{ Amino Acid } & \multicolumn{2}{|c|}{ Patient } & \multirow{2}{*}{ Controls* } \\
\hline & 4th Day & 6th Day & \\
\hline $\begin{array}{l}\text { Hydroxyproline } \\
\text { Aspartic acid } \\
\text { Threonine } \\
\text { Serine } \\
\text { Asparaginet }+ \text { glutamine } \\
\text { Proline } \\
\text { Glutamic acid }+ \\
\text { Citrulline } \\
\text { Glycine } \\
\text { Alanine } \\
\text { Valine } \\
\text { Methionine } \\
\text { Isoleucine } \\
\text { Leucine } \\
\text { Tyrosine } \\
\text { Phenylalanine } \\
\text { Ornithine } \\
\text { Lysine } \\
\text { Histidine } \\
\text { Arginine }\end{array}$ & $\begin{array}{r}0 \\
\operatorname{trace} \\
240 \\
330 \\
5500 \\
1760 \\
- \\
4260 \\
1490 \\
3000 \\
430 \\
470 \\
140 \\
350 \\
1000 \\
- \\
- \\
- \\
-\end{array}$ & $\begin{array}{r}0 \\
\text { trace } \\
240 \\
460 \\
8700 \\
2170 \\
- \\
4570 \\
2050 \\
5580 \\
- \\
900 \\
- \\
390 \\
- \\
50 \\
930 \\
200 \\
0\end{array}$ & $\begin{array}{c}-\S \\
165 \pm 62 \\
181 \pm 93 \\
667 \pm 19 \\
287 \pm 63 \\
- \\
10 \cdot 3 \pm 22 \cdot 3 \\
236 \pm 115 \\
332 \pm 108 \\
224 \pm 75 \\
10 \cdot 1 \pm 26 \cdot 9 \\
69 \cdot 4 \pm 22 \cdot 9 \\
137 \pm 43 \\
153 \pm 50 \\
69 \cdot 6 \pm 55 \cdot 1 \\
154 \pm 30 \\
240 \pm 79 \\
86 \pm 64 \\
-\end{array}$ \\
\hline
\end{tabular}

* Mean value for 6 infants on the 5th day of life (Ghadimi and Pecora, 1964) \pm standard deviation.

tCalculated as glutamine.

$\ddagger$ Not calculated because of overlapping of peaks by other amino acids, present in increased amounts.

$\S$ Not determined.

TABLE II

Amino Acids in CSF Patient with Citrullinaemia $($ (umol/l.)

\begin{tabular}{l|c|c}
\hline \multicolumn{1}{c|}{ Amino Acid } & $\begin{array}{c}\text { Patient } \\
\text { 4th Day }\end{array}$ & Controls \\
\hline Hydroxyproline & 0 & $-\S$ \\
Aspartic acid & Trace & $2 \cdot 9 \pm 2 \cdot 7$ \\
Threonine & 120 & $26 \cdot 6 \pm 9 \cdot 3$ \\
Serine & 310 & $35 \cdot 7 \pm 9 \cdot 6$ \\
Asparaginet + glutamine & 8660 & $455 \pm 121$ \\
Proline & 0 & Trace \\
Glutamic acid + & - & $14 \cdot 7 \pm 13 \cdot 3$ \\
Citrulline & 2560 & $2 \cdot 1 \pm 0 \cdot 7$ \\
Glycine & - & $8 \cdot 5 \pm 2 \cdot 5$ \\
Alanine & 550 & $27 \cdot 9 \pm 9 \cdot 9$ \\
Valine & 140 & $14 \cdot 3 \pm 4 \cdot 0$ \\
Methionine & 340 & $3 \cdot 2 \pm 1 \cdot 0$ \\
Isoleucine & 50 & $5 \cdot 0 \pm 0 \cdot 9$ \\
Leucine & 140 & $11 \cdot 6 \pm 2 \cdot 4$ \\
Tyrosine & 700 & $7 \cdot 9 \pm 2 \cdot 3$ \\
Phenylalanine + & - & $7 \cdot 5 \pm 2 \cdot 2$ \\
Ornithine & Trace & $8 \cdot 4 \pm 2 \cdot 3$ \\
Lysine & 230 & $18 \cdot 6 \pm 6 \cdot 4$ \\
Histidine & 190 & $11 \cdot 1 \pm 2 \cdot 9$ \\
Arginine & 0 & $14 \cdot 2 \pm 7 \cdot 4$ \\
& & \\
\hline
\end{tabular}

ॠ Mean value for 13 subjects aged 9 months to 65 years (Van Sande et al. 1970) \pm standard deviation.

$\dagger \ddagger \S$ See 'Table I.

cine leucine and lysine were increased two to threefold only. Ornithine was the only amino acid present in a decreased concentration. Table II shows the amino acid concentration in the patient's
CSF. An exceptionally high citrulline level was again found. The concentrations of methionine and tyrosine were also markedly raised (about onehundredfold). The amino acids alanine, glutamine histidine lysine, leucine, isoleucine, valine serine, and threonine were present in concentrations 5 to 20 times higher than in normal human subjects.

The urinary excretion of amino acids by the patient is shown in Table III. A very marked

TABLE III

Urinary Excretion of Amino Acids by Patient with Citrullinaemia ( $\mathrm{mg} / \mathrm{mg}$ creatinine)

\begin{tabular}{|c|c|c|}
\hline Amino Acid & $\begin{array}{l}\text { Patient } \\
\text { 4th Day }\end{array}$ & Controls* \\
\hline $\begin{array}{l}\text { Hydroxyproline } \\
\text { Aspartic acid } \\
\text { Threonine } \\
\text { Serinet } \\
\text { Asparaginet + glutamine } \\
\text { Proline } \\
\text { Glutamic acid } \\
\text { Citrulline } \\
\text { Glycine } \\
\text { Alanine } \\
\text { Valine } \\
\text { Methionine } \\
\text { Isoleucine } \\
\text { Leucine } \\
\text { Tyrosine } \\
\text { Phenylalanine } \\
\text { Ornithine } \\
\text { Lysine } \\
\text { Histidine } \\
\text { Arginine }\end{array}$ & $\begin{array}{c}\text { Trace } \\
-8 \\
- \\
5 \cdot 90 \\
3 \cdot 16 \\
1 \cdot 43 \\
13 \cdot 70 \\
1 \cdot 80 \\
3 \cdot 40 \\
0 \cdot 07 \\
- \\
- \\
1.91 \\
- \\
- \\
0.59 \\
0.00\end{array}$ & 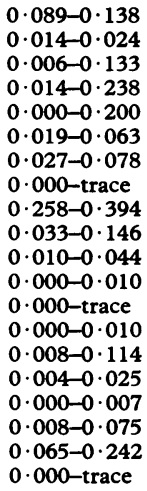 \\
\hline
\end{tabular}

*Values for 5 infants on the 6th day of life (Baumgartner $e t$ i $2 l$. 1968).

$\dagger \ddagger \S$ See Table I.

increased in the citrulline excretion was found. The urinary excretions of glutamine, proline, glutamic acid, glycine, alanine, valine, tyrosine, and histidine were also increased.

The activities of the urea cycle enzymes were found to be somewhat reduced. The most striking finding, however, was the absence of argininosuccinate synthetase activity in the liver and the very low activity of this enzyme in brain (Table IV).

Pathological findings. Necropsy showed a diffuse bilateral pneumonia. Examination of the liver showed a diffuse necrosis in which the cells were affected in groups. In some necrotic parts the pre-existent cell structure was still visible. Glycogen could hardly be found in the liver. Microscopical examination of the brain revealed an intracellular oedema. 
TABLE IV

Activities of Urea Cycle Enzymes in Liver and Brain $(\mu \mathrm{mol} / \mathrm{min} \times g$ wet weight of tissue)

\begin{tabular}{|c|c|c|c|c|}
\hline & $\begin{array}{l}\text { Liver of } \\
\text { Patient }\end{array}$ & Controlst & $\begin{array}{l}\text { Brain of } \\
\text { Patient }\end{array}$ & $\begin{array}{c}\text { Controls } \\
t\end{array}$ \\
\hline $\begin{array}{l}\text { Carbamylphosphate } \\
\text { synthetase } \\
\text { Ornithine trans- } \\
\text { carbamylase } \\
\text { Argininosuccinate- } \\
\text { synthetase } \\
\text { Arginase }\end{array}$ & $\begin{array}{c}0 \cdot 13 \\
2 \cdot 90 \\
\text { Not } \\
\text { detectable } \\
51 \cdot 0\end{array}$ & $\begin{array}{l}0 \cdot 60-0 \cdot 90 \\
9 \cdot 0-12 \cdot 0 \\
0 \cdot 5-1 \cdot 5 \\
238-800\end{array}$ & $\begin{array}{c}\ddagger \\
0.29 \\
0.06 \\
0.69\end{array}$ & $\begin{array}{l}0 \cdot 40 \\
3 \cdot 45 \\
=\end{array}$ \\
\hline
\end{tabular}

*Pieces of liver and brain, obtained one hour after death, were immediately frozen in liquid $\mathrm{N}_{2}$ and preserved at $-70^{\circ} \mathrm{C}$.

tNormal control liver tissue was obtained surgically from traffic accident cases and analysed immediately.

$\$$ Not determined.

\section{Discussion}

The extremely high level of citrulline in serum and CSF, coupled with the argininosuccinate synthetase deficiency in liver and brain verified that this infant was suffering from citrullinaemia. The clinical picture of this patient differs greatly from that of the patients reported previously (McMurray et al., 1963; Morrow et al., 1967), in whom the first symptoms of the disease appeared during the first year of life with mental retardation, and periods of irritability, vomiting, and semicoma, sometimes combined with convulsions. A low protein diet was of benefit in these patients.

The clinical course of our patient was fulminating with very early death at the seventh day. A protein-free diet, given from the fifth day of life, was of no benefit. The only sib of the patient also suddenly died after three days of apparently normal development. His clinical features strongly resembled those of the proband and it is likely that he suffered from the same disease. A similar case has recently been published by Wick et al. (1970). In another inborn error of metabolism of the urea cycle argininosuccinicaciduria the clinical features can be very similar to that observed in our patient (Baumgartner et al., 1968; Carton et al., 1969). Therefore, citrullinaemia should be added to the list of inborn errors of metabolism which may have a fulminating and often fatal neonatal course. These include maple syrup urine disease, nonketotic hyperglycinaemia, argininosuccinic aciduria propionic acidaemia methylmalonic acidaemia, isovaleric acidaemia, and galactosaemia.

The biochemical abnormalities of our case also differ from previously reported cases. The citrulline concentration in blood, CSF, and urine was considerably higher, and the derangement of the amino acid pattern of blood was much greater in our patient. McMurray et al. (1963) and Morrow (1967) found, apart from the very high citrulline levels, only an increase of glutamic acid and methionine and a decrease of ornithine in the serum of their patients. In our patient, however, the concentration of most amino acids was greatly increased (Table I).

In a sample of liver obtained at necropsy, no argininosuccinate synthetase activity could be found. The value for this enzyme activity in a liver biopsy specimen in McMurray's case was between 4 and $8 \%$ of the activities found in two controls. The more fulminant clinical course and greater biochemical disturbance suggests an almost complete deficiency of argininosuccinate synthetase. This has indeed been found in liver.

The variation in the clinical and biochemical characteristics of our patient as compared to the cases of citrullinaemia reported previously could be another example of genetic heterogeneity. In an enzymic block of the urea cycle it would be expected that the patient would be unable to produce urea and arginine. We could not detect arginine in the serum of our patient. Tedesco and Mellman (1967) have shown a twenty-fivefold increase in the $\mathrm{K}_{\mathrm{m}}$ for citrulline of argininosuccinate synthetase of a patient suffering from citrullinaemia. Mutations of the active centre of the enzyme, and particularly of the site responsible for the binding of citrulline, are therefore possibleco without a complete loss of enzyme activity. It is suggested that a similar mutation has taken place in this case. The very high citrulline levels observed here suggest an even further increased $\mathrm{K}_{\mathrm{m}}$ for citrulline. The urea level in serum was normal, an observation that has also been made in other urea cycle disorders like ornithine transcarbamylase deficiency (Russell et al., 1962) and argininosuccinase deficiency (Allan et al., 1958). Unfortunately, we did not have the opportunity to determine the plasma ammonia concentration.

The hypoglycaemia found in the patient on admission to our hospital might be caused by a high insulin level brought about by the extreme hyperaminoacidaemia (Floyd et al., 1966). Räihä and Suihkonen (1968) have shown that urea cycle enzymes are fully developed in the liver of a newborn. Nevertheless, we found a decreased activity of all urea cycle enzymes in this patient. A possible explanation for this finding may be found in a decreased enzyme induction. Schimke (1962) and recently Szepesi and Freedland (1969) have shown that the urea cycle enzymes can be induced by a high protein intake. The patient received no protein for at least two days before death. This 
lack of protein may be part of the explanation for the low activities of the enzymes of the urea cycle found.

We wish to thank Dr. P. Vooys and Dr. J. Slooff, who performed the pathological examination, and Dr. J. Barents for giving us the opportunity to examine this patient.

\section{REFERENCES}

Allan, J. D., Cusworth, D. C., Dent, C. E., and Wilson, V. K. (1958). A disease, probably hereditary, characterized by severe mental deficiency and a constant gross abnormality of aminoacid metabolism. Lancet, 1, 182.

Baumgartner, R., Scheidegger, S., Stalder, G., and Hottinger, A. (1968). Argininbernsteinsäure-Krankheit des Neugeborenen mit letalem Verlauf. Helvetica Paediatrica Acta, 23, 77.

Brown, G. W., Jr., and Cohen, P. P. (1959). Comparative biochemistry of urea synthesis. I. Methods for the quantitative assay of urea cycle enzymes in liver. Fournal of Biological Chemistry, 234, 1769.

Carton, D., de Schrijver, F., Kint, J., van Durme, J., and Hooft, C. (1969). Argininosuccinic aciduria: neonatal variant with rapid fatal course. Acta Paediatrica Scandinavica, 58, 528.

Floyd, J. C., Jr., Fajans, S. S., Conn, J. W., Knopf, R. F., and Rull, J. (1966). Stimulation of insulin secretion by amino acids. fournal of Clinical Investigation, 45, 1487.

Ghadimi, H., and Pecora, P. (1964). Plasma amino acids after birth. Pediatrics, 34, 182.

McMurray, W. C., Mohyuddin, F., Bayer, S. M., and Rathbun, J. C. (1964). Citrullinuria : a disorder of amino acid metabolism associated with mental retardation. In Proceedings of the International Congress on the Scientific Study of Mental Retardation, Copenhagen, 1964, vol. 1, p. 117. Ed. by J. Oster and H. V. Sletved. Copenhagen, Denmark.
McMurray, W. C., Mohyuddin, F., Rossiter, R. J., Rathbun, J. C., Valentine, G. H., Koegler, S. J., and Zarfas, D. E. (1962). Citrullinuria: a new aminoaciduria associated with mental retardation. Lancet, 1, 138.

McMurray, W. C., Rathbun, J. C., Mohyuddin, F., and Koegler, S. J. (1963). Citrullinuria. Pediatrics, 32, 347.

Mohyuddin, F., Rathbun, J. C., and McMurray, W. C. (1967). Studies on amino acid metabolism in citrullinuria. American fournal of Diseases of Children, 113, 152.

Morrow, G. (1967). Citrullinemia. American fournal of Diseases of Children, 113, 157.

Morrow, G., III, Barness, L. A., and Efron, M. L. (1967). Citrullinemia with defective urea production. Pediatrics, 40, 565.

Räihä, N. C. R., and Suihkonen, J. (1968). Development of ureasynthesizing enzymes in human liver. Acta Paediatrica Scandinavica, 57, 121 .

Russell, A., Levin, B., Oberholzer, V. G., and Sinclair, L. (1962). Hyperammonaemia: a new instance of an inborn enzymatic defect of the biosynthesis of urea. Lancet, $2,699$.

Schimke, R. T. (1962). Adaptive characteristics of urea cycle enzymes in the rat. Fournal of Biological Chemistry, 237, 459.

Szepesi, B., and Freedland, R. A. (1969). Time-course of enzyme adaptation. II. The rate of change in two urea cycle enzymes. Life Sciences, 8, 1067.

Tedesco, T. A., and Mellman, W. J. (1967). Argininosuccinate synthetase activity and citrulline metabolism in cells cultured from a citrullinemic subject. Proceedings of the National Academy of Sciences of the United States of America, 57, 829.

Van Sande, M., Mardens, Y., Adriaenssens, K., and Lowenthal, A. (1970). The free amino acids in human cerebrospinal fluid. fournal of Neurochemistry, 17, 125.

Wick, H., Brechbühler, T., and Girard, J. (1970). Citrullinemia: elevated serum citrulline levels in healthy siblings. Experientia, 26, 823.

Correspondence to Dr. S. P. M. van der Zee, Department of Paediatrics, University of Nijmegen, Nijmegen, The Netherlands. 